\title{
Brain soluble protein patterns during shock avoidance conditioning*
}

\section{JOHN GAITO and ROBERT W. HOPKINS \\ York University, Downsview, Ontario, Canada}

Two shock avoidance conditioning experiments were conducted; soluble acidic proteins were extracted from brain tissue and analyzed by polyacrylamide gel electrophoresis. Electrophoretic patterns of the five prealbumin bands for conditioned rats was the same as for shocked and nonshocked control animals.

There is now available much research which indicates that, during learning and other behaviors, changes in the amount of RNA and protein usually occur (Gaito, 1971). There is the assumption that DNA sites which are completely, or relatively, quiescent are stimulated to become active to produce RNA, which event ultimately results in protein synthesis (Bonner, 1966; Gaito, 1964, 1971). It is, therefore, possible that cells involved in a learning task have a slightly different protein complement than before involvement. Consequently, the electrophoretic pattern of the proteins from a learning animal may be qualitatively or quantitatively different.

There are two classes of proteins that have been considered to be regulators of DNA activity for RNA synthesis: histones and acidic proteins (Busch, 1965; Bonner et al, 1968). In previous studies in this laboratory (Hopkins, Gaito, \& Howick, 1973), it was found that the electrophoretic patterns of histones of shock avoidance conditioned rats and visually stimulated rats were the same as those of control animals. This is not surprising, for the histones are a relatively homogeneous set of proteins and vary little between tissues and species. However, the acidic proteins show both tissue and species specificity (Wang, 1972). While the histones tend to parallel DNA in their stability, the acidic proteins seem to show variability similar to RNA. For example, the latter show high rates of turnover and tend to be associated with gene activity (Busch, 1965). Dingman \& Sporn (1964) reported that with chickens inactive genetic material contained modest amounts of RNA and nonhistone proteins; these chemicals were abundant in genetic material, showing cellular activity.

An acidic protein that has been assumed to be specific to the brain has been indicated recently (Moore et al, 1968; McEwen \& Hyden, 1966; Kawakita, 1972). This S-100 protein has been reported to vary between experimental and control animals during learning phenomena (Yanagahira \& Hyden, 1971).

Some acidic proteins are complexed in chromatin, whereas others are dispersed throughout the cell. The present paper is concerned with polyacrylamide gel

*This research was supported by grants from the National Research Council of Canada (APA-122) and the President's NRC Fund of York University (Grant No. 32). The paper is sponsored by Howard Flock, who takes full editorial responsibility for it. electrophoresis patterns of the latter acidic proteins in the prealbumin region (PAR) for rats during a shock avoidance task. The S-100 protein is supposed to be located in PAR (Kawakita, 1972). In two experiments, the results indicate that the gross electrophoretic patterns of shock avoidance rats, shocked control rats, and nonshocked control rats are the same. In addition, a semiquantitative analysis of the five bands in PAR indicate no significant differences between the three groups of rats in any band.

\section{METHOD \\ Behavioral}

Two experiments were conducted with shock avoidance conditioning. The Ss were male Wistar strain rats (littermates), varying in age from 100 to 150 days. Three adjacent shuttleboxes were used, so that in each litter two control animals could be yoked to the experimental rat $(E)$. Each of the three units consisted of two chambers with metal grill floors. For one yoked control animal (CNS, nonshock), neither chamber was electrified. For the other control rat (CS, shock), both chambers were electrified during the time that the $\mathrm{E}$ animal was receiving shock. The E rat had one of the two chambers capable of being electrified. Twenty trials of 1 -min duration were provided for all rats.

In Experiment 1 there were six E, three CNS, and three CS rats; in Experiment 2 there were eight $\mathrm{E}$, five $\mathrm{CNS}$, and three $\mathrm{CS}$ animals.

\section{Chemical}

Each rat was sacrificed by immersion in liquid nitrogen for $10 \mathrm{sec}$. The brain was rapidly removed; the olfactory bulbs, cerebellum, and brain stem parts below the cerebellum were deleted; the remainder was sectioned into two parts (ventral brain and dorsal brain) by a horizontal cut at the rhinal fissure. Each sample was homogenized in distilled water and centrifuged at $20,000 \mathrm{xg}$ in a Sorvall centrifuge for $30 \mathrm{~min}$ (Kawakita 1972). The supernatant containing the soluble proteins was used for the electrophoretic analyses.

Fifty microliter samples were layered on polyacrylamide gel and run in electrophoresis apparatus (Davis, 1964). A 10\% gel was used for most samples because preliminary work indicated that $10 \%$ gel provided better resolution and a more distinctive pattern for the five PAR bands than did $7.5 \%$ or $15 \%$ gels. But a few samples were run on $15 \%$ gels. The gels were then scanned by a Joyce Loebl chromoscan.

Two checks were provided to determine the location of the albumin band. (1) Bovine albumin (Mann-Schwartz) was run in a separate gel to serve as a marker (intergel albumin). (2) Albumin was added to a few brain samples to ascertain the effect on the five bands (intragel albumin).

\section{RESULTS AND DISCUSSION}

The intragel albumin and intergel albumin checks provided a clear identification of the albumin band, just posterior to Band 5. The addition of albumin to the samples (intragel albumin check) had no effect on Bands 1 and 4. However, Band 5 was modified slightly in shape and its magnitude increased. This effect is not surprising inasmuch as the albumin is adjacent to Band 5.

The difference between $10 \%$ and $15 \%$ gels was slight. 
Table 1

Mean Values for Both Experiments Combined*

\begin{tabular}{|c|c|c|c|c|c|c|c|c|c|c|}
\hline & \multicolumn{5}{|c|}{ Ventral Brain } & \multicolumn{5}{|c|}{ Dorsal Brain } \\
\hline & $B_{1}$ & $\mathbf{B}_{2}$ & $\mathbf{B}_{3}$ & $\mathrm{~B}_{4}$ & $B_{3}$ & $B_{1}$ & $\mathbf{B}_{2}$ & $\mathbf{B}_{3}$ & $\mathrm{~B}_{4}$ & $\mathbf{B}_{3}$ \\
\hline & \multicolumn{10}{|c|}{ Semiquantitative Data } \\
\hline $\begin{array}{l}\text { E } \\
\text { CS } \\
\text { CNS }\end{array}$ & $\begin{array}{l}10 \\
13 \\
11\end{array}$ & $\begin{array}{l}18 \\
23 \\
17\end{array}$ & $\begin{array}{l}30 \\
35 \\
23\end{array}$ & $\begin{array}{l}24 \\
29 \\
22\end{array}$ & $\begin{array}{l}60 \\
74 \\
63\end{array}$ & $\begin{array}{l}14 \\
13 \\
16\end{array}$ & $\begin{array}{l}18 \\
24 \\
22\end{array}$ & $\begin{array}{l}31 \\
46 \\
37\end{array}$ & $\begin{array}{l}28 \\
23 \\
39\end{array}$ & $\begin{array}{l}59 \\
76 \\
74\end{array}$ \\
\hline & \multicolumn{10}{|c|}{ Relative Proportion Data } \\
\hline $\begin{array}{l}\text { E } \\
\text { CS } \\
\text { CNS }\end{array}$ & $\begin{array}{l}7 \\
8 \\
8\end{array}$ & $\begin{array}{l}12 \\
14 \\
13\end{array}$ & $\begin{array}{l}19 \\
19 \\
17\end{array}$ & $\begin{array}{l}16 \\
17 \\
16\end{array}$ & $\begin{array}{l}46 \\
42 \\
46\end{array}$ & $\begin{array}{r}10 \\
7 \\
9\end{array}$ & $\begin{array}{l}13 \\
12 \\
13\end{array}$ & $\begin{array}{l}19 \\
23 \\
20\end{array}$ & $\begin{array}{l}19 \\
18 \\
20\end{array}$ & $\begin{array}{l}40 \\
41 \\
38 \\
\end{array}$ \\
\hline
\end{tabular}

*There were $14 \mathrm{E}, 8 \mathrm{CNS}$, and $6 \mathrm{CS}$ rats.

Both give five bands but the $15 \%$ gel tends to obscure Band 2 somewhat.

The electrophoretic patterns obtained in these experiments were typical of those reported in the literature (e.g., Kawakita, 1972). In each experiment, semiquantitative analyses were attempted. The gels were run in a Joyce Loebl chromoscan and the area in each of the five bands was determined (semiquantitative data). These values were then evaluated with analysis of variance procedures for VB and DB separately in each experiment. In neither experiment were there any significant differences in the overall analysis (the region for rejection of the null hypothesis was .05). In addition, the three groups of rats were contrasted for each band separately. Again no significant differences were detected in either experiment.

A second set of analyses was conducted by dividing the value for each band by the total values of all five $b$ ands (relative proportion data). No significant differences emerged when the three groups were contrasted by analysis of variance procedures for each band in the two experiments.

The results of both experiments were combined and analysis of variance procedures were used for the analyses. Again no significant differences were detected in any analysis. The means of both the semiquantitative and relative proportion values for the combined data are indicated in Table 1.

These results may mean that there are no differences in electrophoretic patterns between shock avoidance conditioned animals and control rats. However, it should be recognized that the tissue analyzed was of gross nature in contrast to the tissue used by Yanagahira \& Hyden (1971). They used single cells from the dorsal cortex.

Thus, although these results are suggestive, further research is planned using more refined procedures.
Further breakdown of tissue is anticipated so as to sample more discrete tissue. Also, specific portions of the PAR bands may be removed and subjected to further electrophoretic runs at different percentages of polyacrylamide gel so as to attain further resolution of the soluble protein bands. Another possible refinement is the evaluation of acidic proteins in chromatin, in contrast to acidic proteins from the whole cell (as in the present study).

\section{REFERENCES}

Bonner, J. Molecular biological approaches to the study of memory. In J. Gaito (Ed.), Macromolecules and behavior. Vol. 1. New York: A ppleton-Century-Crofts, 1966.

Bonner, J., Dahmus, M. E., Fambrough, E., Huang, R. C., Marushige, K., \& Yuan, D. The biology of isolated chromatin. Science, 1968, 159, 47-56.

Busch, H. Histones and other nuclear proteins. New York: Academic Press, 1965.

Davis, B. J. Disc electrophoresis: II. Method and application to human serum proteins. Annals of New York Academy of Sciences, 1964, 121, 404-427.

Dingman, W., \& Sporn, M. B. Studies on chromatin: I. Isolation and characterization of nuclear complexes of deoxyribonucleic acid, ribonucleic acid, and protein from embryonic and adult tissues of the chicken. Journal of Biological Chemistry, 1964, 239, 3483-3492.

Gaito, J. DNA derepression and behavior. Psychological Reports, $1964,15,276$.

Gaito, J. DNA complex and adaptive behavior. Englewood Cliffs, N.J: Prentice-Hall, 1971.

Hopkins, R. W., Gaito, J., \& Howick, D. Electrophoretic histone patterns during shock avoidance conditioning and visual patterns duriotion. International Journal of Psychobiology, 1973, in stimulat

Kawakita, H. Immunochemical studies on the brain specific protein. Journal of Neurochemistry, 1972, 19, 87-93.

McEwen, B. S., \& Hyden, H. A study of specific brain proteins on the semi-micron scale. Journal of Neurochemistry, 1966 , $13,823-833$.

Moore, B. W., Perez, V. J., \& Gehring, M. Assay and regional distribution of a soluble protein characteristic of the nervous system. Journal of Neurochemistry, 1968, 15, 265-272.

Wang T. Y Tissue specificity on non-histone chromosomal proteins. Experimental Cell Research, 1972, 69, 217-219.

Yanagihara, T., \& Hyden, H. Protein synthesis in various regions of rat hippocampus during learning. Experimental Neurology, 1971, 31, 151-164.

(Received for publication March 12, 1973.) 